\title{
SPATIAL DISTRIBUTION OF EGGS AND LARVAE OF ENGRAULIS ANCHOITA (HUBBS \& MARINI, 1935) IN THE SOUTHERN BRAZILIAN SHELF
}

\author{
TORQUATO, F.O. \& MUELBERT, J.H. \\ Laboratório de Ecologia do Ictioplâncton, Instituto de Oceanografia \\ Universidade Federal do Rio Grande, Av. Itália s/n, Carreiros, Rio Grande-RS, Brasil. \\ *Corresponding author: felipe_o_torquato@hotmail.com
}

\begin{abstract}
Torquato, F.O. \& Muelbert, J.H. (2015). Spatial distribution of eggs and larvae of Engraulis anchoita (hubbs \& marini, 1935 ) in the southern brazilian shelf. Braz. J. Aquat. Sci. Technol. 19(3). E ISSN 1983-9057. DOI 10.14210/bjast. v19n3. This paper describes the horizontal distribution patterns of eggs and larvae of the anchovy, Engraulis anchoita, at two distinct oceanographic regions in the Southern Brazilian Shelf (SBS). Santa Marta Cape (SMC; $28^{\circ} 30^{\prime}$ ) is characterized by upwelling events, while Albardão $\left(33^{\circ}\right)$ is influenced by Plata Plume Waters (PPW) and the Subtropical Shelf Front (SSF). Ichthyoplankton was sampled during winter 2005 and summer 2007 at SMC and Albardão at night and daytime with a Multinet. Three $330 \mu \mathrm{m}$ mesh-nets results were combined to express the horizontal distribution of anchovy early stages. Maps of salinity, temperature, fish eggs and larvae were made to evaluate spatial distributional patterns. TemperatureSalinity-Icthyoplankton (TSI) diagrams were used to infer fish larvae distribution with respect to water mass composition. According to TSI diagrams, PPW was found in both regions and was positively associated with ichthyoplankton abundance. Mean larvae and eggs abundance during winter were greater than summer and ichthyoplankton was more abundant in SMC than off Albardão. At both seasons, eggs and larvae were usually present in cold waters. The highest concentration of anchovy eggs and larvae were found in coastal areas with low salinity during winter and summer.
\end{abstract}

Keywords: Horizontal distribution, Ichthyoplankton, Subtropical Shelf Front, Upwelling, Plata Plume Water, Anchovy.

\section{INTRODUCTION}

Almost all planktonic organisms, including fish eggs and larvae are found heterogeneously distributed in the environment (Santos et al., 2006) as a result of both active behavior and passive transport mechanisms that control their distribution. These mechanisms outcome from a combination of biotic and abiotic factors of which the main physical variables are mixing, stratification, river discharge and wind (Norcross \& Shaw, 1984). Therefore, changes in spatial and temporal distribution of ichthyoplankton are deeply linked to variation in environmental factors (Sabatés \& Olivar, 1996; Munk et al., 1999). However, the majority studies carried out across the Southern Brazilian Shelf (SBS) are restricted to either only one season (Franco \& Muelbert, 2003; Franco et al., 2006) or geographic limitation (Matsuura et al., 1992; Matsuura \& Kitahara, 1995), precluding discussions about how eggs and larvae change their distribution throughout seasons and locations.

The SBS is part of the western boundary margin of the South Atlantic Ocean, delimited to the north by Santa Marta Cape $\left(28^{\circ} 30^{\prime} \mathrm{S} ; 48^{\circ} \mathrm{W}\right)$ and to the south by Arroio Chuí $\left(33^{\circ} \mathrm{S} ; 53^{\circ} \mathrm{W}\right.$ ) (Franco et al., 2006). The region is known as spawning, feeding and growth area for one of the most important pelagic fish in the Southwest Atlantic, Engraulis anchoita (Castello, 1997a). The decrease in its abundance should cause serious impact in energy flow across the ecosystem since the species is food source for many other marine organisms (Ivanovic \& Brunetti, 1994; Frere et al., 1996; Naya, 2002).

Larval, post-larval and young-of-the-year of $E$. anchoita are found in coastal waters throughout the year, but the species is most abundant during winter and spring when it is the peak of reproduction (Matsuura, 1992; Castello, 1997b). Studies about E. anchoita have drawn attention to spawning in SBS where growth areas of this species are linked to both coastal upwelling systems in Santa Marta Cape (SMC) and under influence of Subtropical convergence in extreme southern Brazil (Franco et al., 2005).

Coastal fronts in the South America are poorly studied and in many cases biological data are dissociated from physical oceanographic processes (Acha et al., 2004). Among the important oceanographic areas, Santa Marta Cape is characterized by the influence of different water masses: Tropical Water (TW), South Atlantic Central Water (SACW), Shelf Water (SW), Coastal Water (CW), and the Plata Plume Water (PPW) that can reach the region during winter (Acha et al., 2004; Piola et al., 2008; Campos, 2010). In SMC the shelf is narrow and rather steep, and it is characterized by warm, saline and oligotrophic TW at surface covering cooler, fresh and nutrient-rich SACW. The wind is predominantly NE and moderate during summer, when in contact with the sea surface pro- 
motes offshore Ekman transport near the surface and forces an upwelling condition at the coast. On the other hand, during wintertime the coastal region undergoes a thermal inversion, causing weak stratification during this season (Matsuura, 1996; Castelão et al. 2004).

Off Albardão is a region where Subtropical Shelf Water (STSW) and Subantartic Shelf Water (SASW) meet, originating the Subtropical Shelf Front (STSF) (Piola et al., 2000). Furthermore, STSF is located just north from the mouth of the Río de la Plata which discharges large volumes of fresh water on western South Atlantic shelf, the Plata Plume Water (PPW), and promotes the presence of a strong frontal system in the Albardão region (Muelbert et al., 2008). The proprieties of STSW and SASW, and the amount of freshwater inputted vary annually (Möller et al., 2008; Piola et al., 2000 ) causing significant impact on physical, chemical and biological properties near-shore marine ecosystem (Muelbert et al., 2008).

This study analyzed the cross-shore distribution of eggs and larvae of Engraulis anchoita at these two peculiar oceanographic regions. The main goal is to understand how spatial cross-shore distribution of early stages is influenced by water discharged from Río de la Plata and upwelling at Santa Marta Cape.

\section{MATERIAL AND METHODS}

Data were gathered during two interdisciplinary research cruises in winter 2005 and summer 2007 (PRONEX I and II, respectively) along the SMC

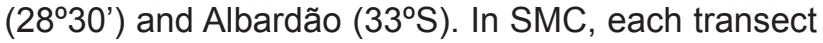
was comprised of five stations spaced 14 miles apart that resulted in 15 stations sampled during each season. Whereas, Off Albardão surveys were composed of three transects perpendicular to the coast, each comprised of six stations spaced 17 miles apart that yielded 18 stations sampled during each season (Figure 1).

Ichthyoplankton was collected during night and daytime with a Multinet $0.25 \mathrm{~m}^{2}$ towed at 2 knots, equipped with two $200 \mu \mathrm{m}$ mesh nets and three $330 \mu \mathrm{m}$ mesh nets. An internal and an external flow-meter were mounted in the net frame to control filtration efficiency and determine volume of water filtered. In this study, data from the three $330 \mu \mathrm{m}$ mesh nets were combined to express the horizontal distribution of $E$. anchoita eggs and larvae while data from $200 \mu \mathrm{m}$ mesh nets were not considered. All samples were preserved in $4 \%$ borax buffered formaldehyde. Anchovy eggs and larvae were subsequently sorted, counted, measured and their abundance was standardized to $100 \mathrm{~m}^{3}$. Temperature and salinity were taken at each station with a Seabird 19E CTD.

Maps of salinity, temperature, fish eggs and larvae were made with Ocean Data View 3.4.1 to

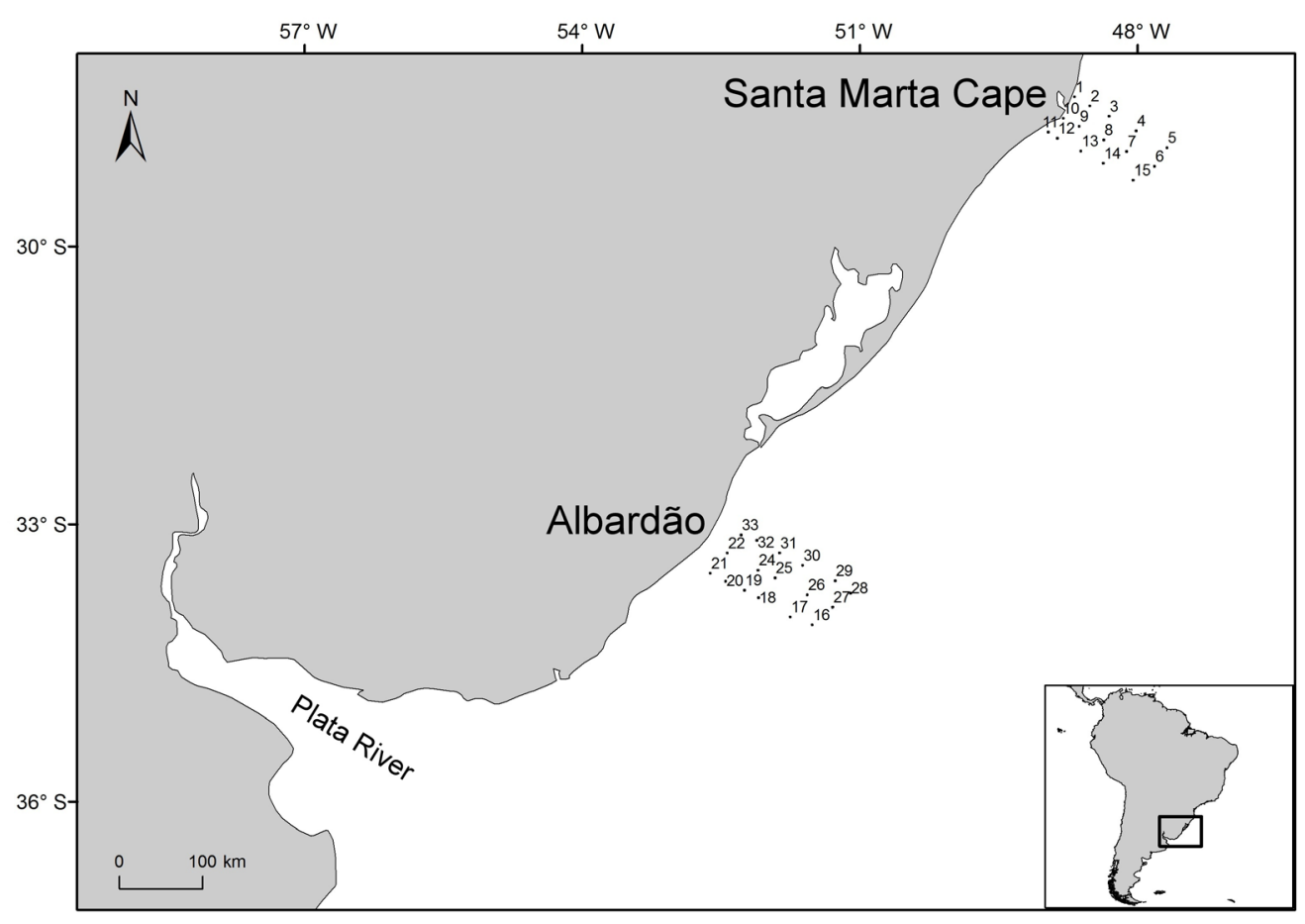

Figure 1 - Distribution of stations in three transects occupied during winter 2005 and summer 2007 in Santa Marta Cape (North) and Albardão (South). 
evaluate spatial distributional patterns. TemperatureSalinity-Icthyoplankton (TSI) diagrams were used to infer fish larvae distribution with respect to water mass composition. Mean abundance of eggs and larvae were compared between seasons and regions using a t-test (Zar, 1999).

\section{RESULTS}

A total of 265 larvae and 324 eggs were recorded during this study. Santa Marta Cape presented higher ichthyoplankton abundance than off Albardão (t-test, $p<0.05)$, and in both areas mean larval and egg abundance during winter was higher than in summer (t-test, $p<0.001)$ (Table 1).

Table 1 - Mean abundance (ind.100m-3) values for E. anchoita eggs and larvae in Santa Marta Cape and Albardão during winter 2005 and summer 2007. Standard errors are shown within brackets.

\begin{tabular}{lcccc}
\hline \hline & \multicolumn{2}{c}{ Santa Marta Cape } & \multicolumn{2}{c}{ Albardão } \\
& Eggs & Larvae & Eggs & Larvae \\
\hline Winter 2005 & $14.05(5.03)$ & $17.78(11.71)$ & $8.30(5.48)$ & $1.85(0.95)$ \\
Summer 2007 & $0.13(0.13)$ & $1.08(0.75)$ & $0.11(0.11)$ & $0.75(0.33)$ \\
\hline \hline
\end{tabular}

\section{Winter}

In Santa Marta Cape, surface temperature ranged from 17.66 to $22.5^{\circ} \mathrm{C}$ (Figure 2a,b). The coldest waters were found close to the shore and southward, whereas the warmest stations were offshore. The same pattern was shown for salinity, with low salinity waters close to the coast and toward south, and high salinity waters offshore (Figure 2c,d). Ichthyoplankton was present in regions with low temperature and salinity, and close to the shore (Figure 2). Eggs were confined to the shore areas, with the highest abundance reaching 55.17 eggs. $100 \mathrm{~m}-3$ (station 9) (Figure 2a,c). The highest abundance of larvae was also close to coast (176 larval.100 m-3, at station 10), but larvae were also present toward offshore (Figure 2b,d). TSI diagrams revealed that ichthyoplankton abundance was mainly associated with waters from STSW and PPW (Figure 3a).
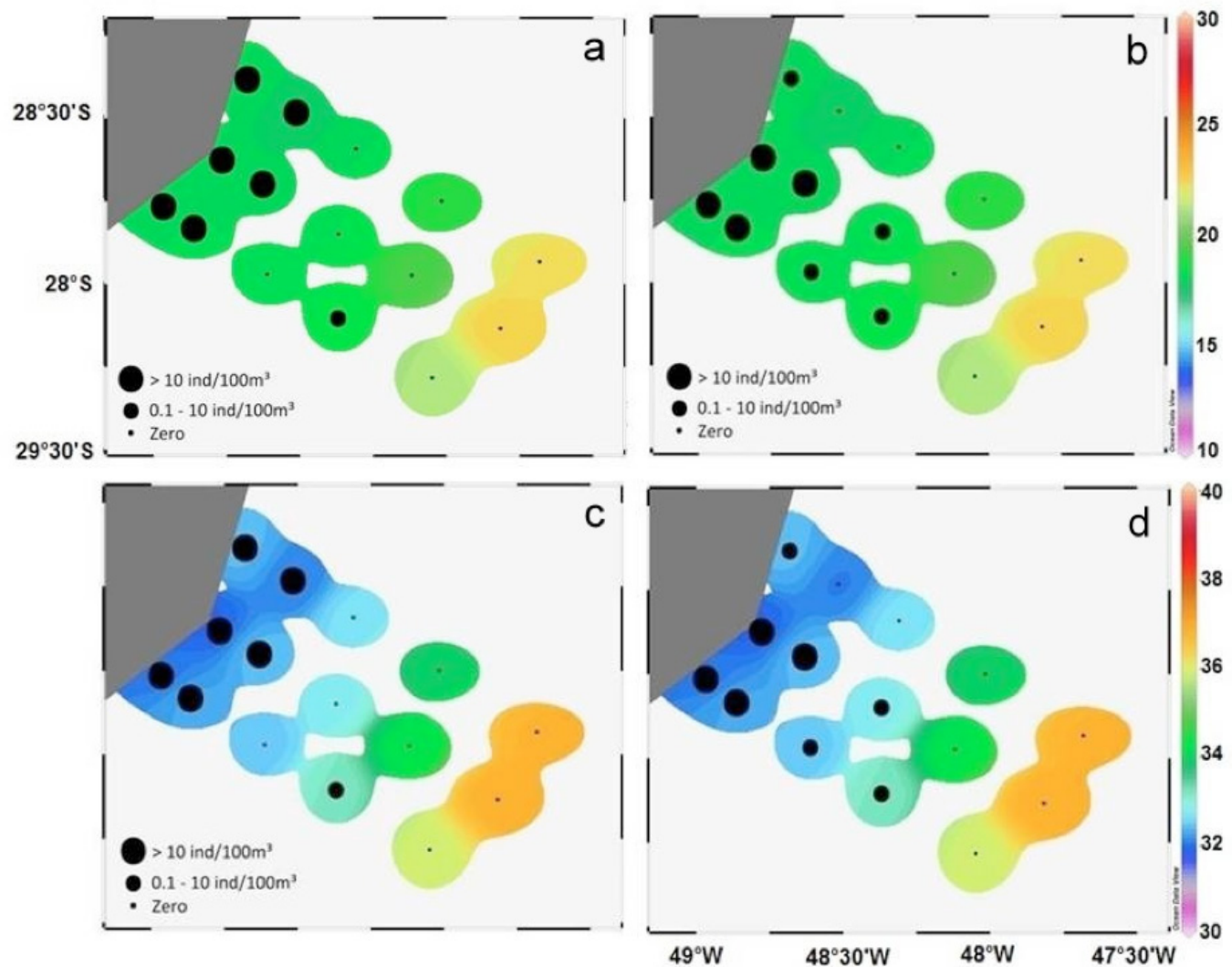

Figure 2 - Distributional patterns observed in Santa Marta Cape during winter 2005. Abundance of E. anchoita eggs (a,c) and larvae (b,d). Temperature $(a, b)$ and salinity $(c, d)$ are represented by colors according to the vertical palette. 

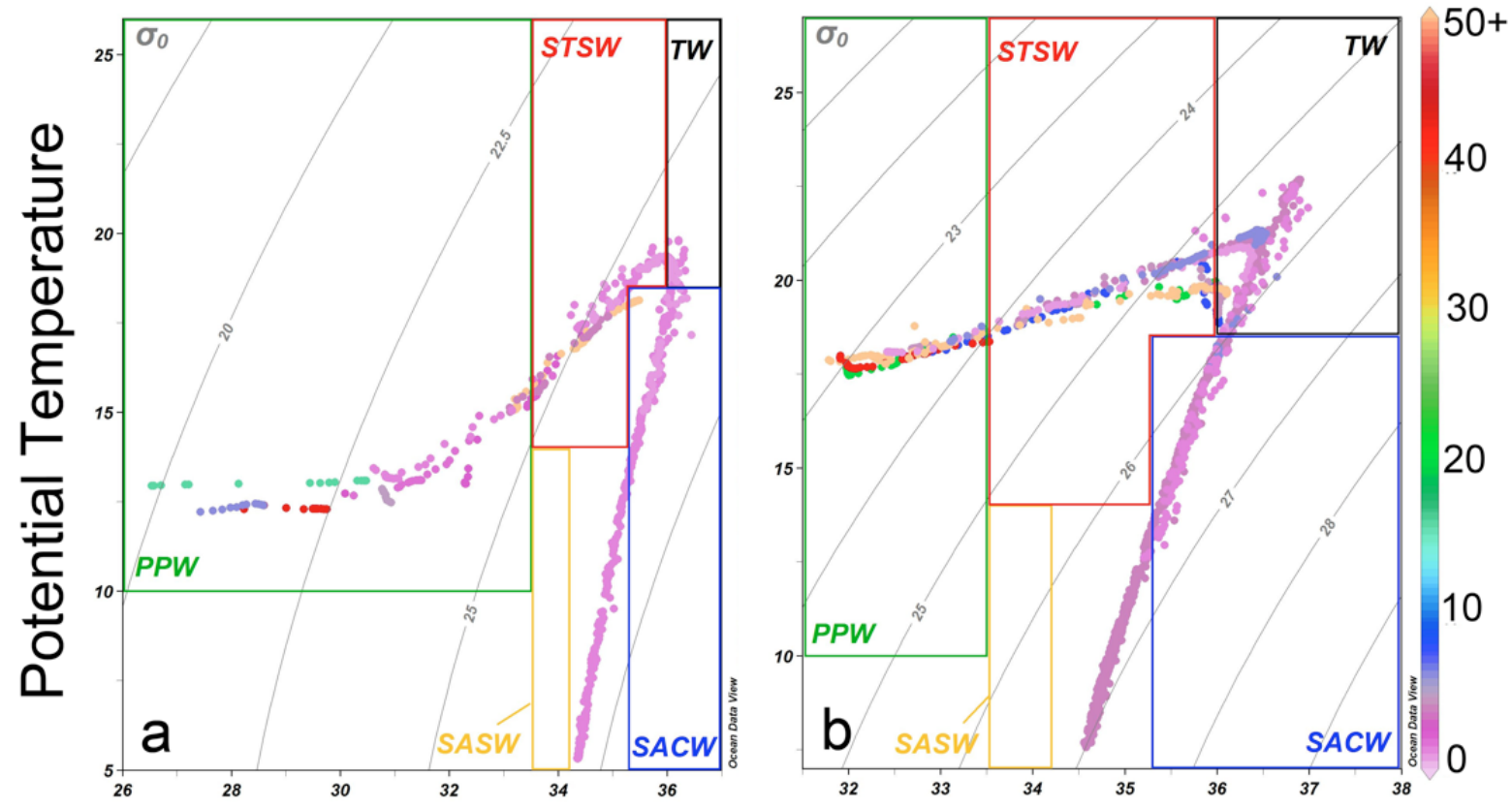

\section{Salinity}

Figure 3 - TSI diagrams with eggs and larvae abundance across different water masses during winter 2005. a) Santa Marta Cape. B) Albardão. Color bar represents ichthyoplankton abundance (ind.100m-3).

Off Albardão, surface temperature varied from 12.21 to $18.35^{\circ} \mathrm{C}$ (Figure $\left.4 \mathrm{a}, \mathrm{b}\right)$. The coldest waters were found close to the coast and southward, whereas the warmest stations were found toward the edge of shelf. The lowest salinity values were found near the shore, whereas the maximum values were found toward the oceanic region (Figure 4c,d).
Ichthyoplankton abundance was higher in coastal areas and southward, with a peak of larvae at station 4 (4.32 ind.100 m-3) and eggs at 19 (88.21 eggs. 100 $m-3)$ (Figure 4). TSI diagram showed that the abundance of larvae and eggs were higher in areas under influence of both water outflow from Río de la Plata and STSW (Figure 3b).
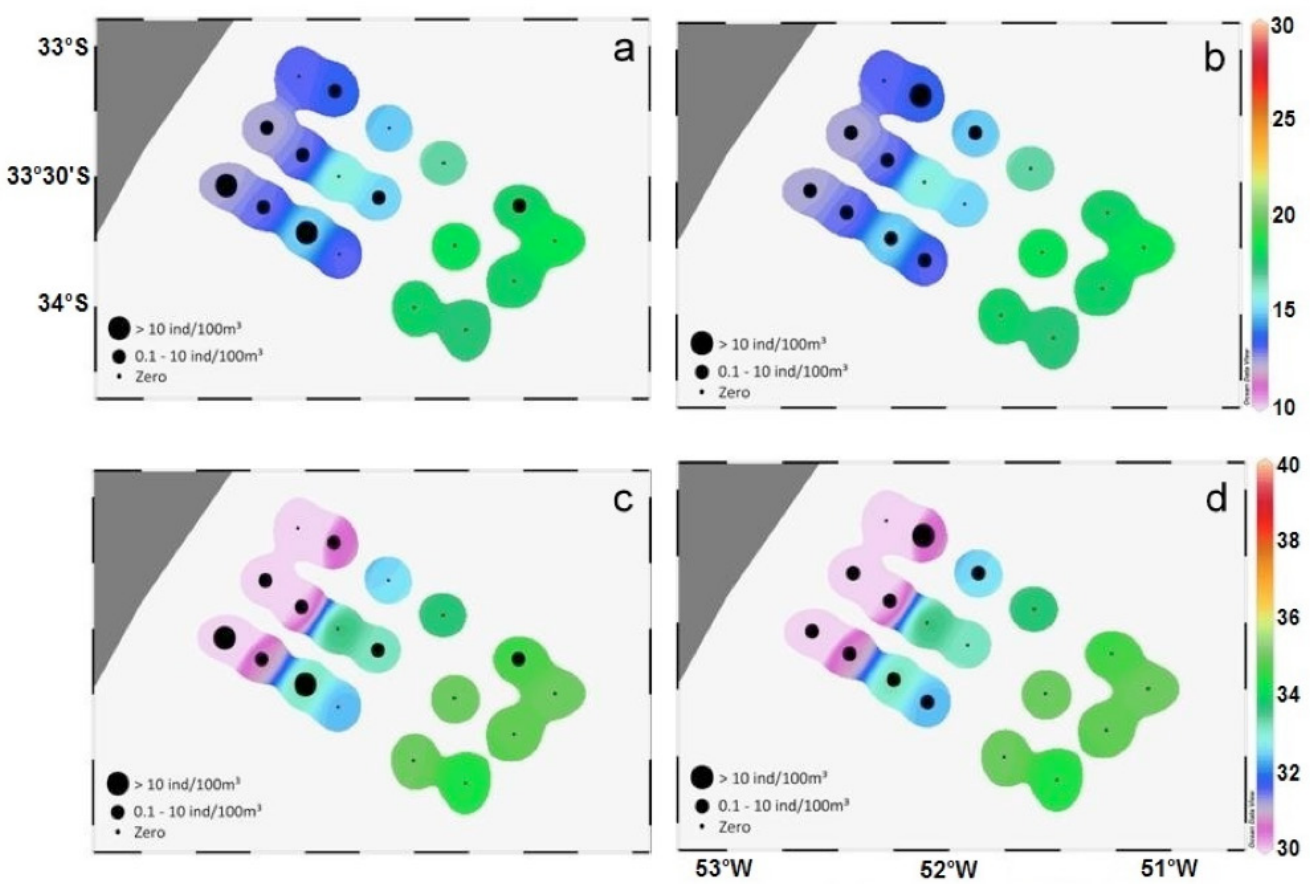

Figure 4 - Distributional patterns observed in Albardão during winter 2005. Abundance of $E$. anchoita eggs (a,c) and larvae (b,d). Temperature $(a, b)$ and salinity $(c, d)$ are represented by colors according to the vertical palette. 


\section{Summer}

In Santa Marta Cape, surface temperature varied from 18.09 to $26.32^{\circ} \mathrm{C}$ (Figure $5 a, b$ ). The warmest waters were located northward (stations 3 and 4), whereas the coldest waters were found close to the coast. Surface salinity varied little among stations with minimum and maximum of 35.38 and
36.54 respectively (Figure $5 \mathrm{c}, \mathrm{d}$ ). Ichthyoplankton was presented only in four stations, larvae were recorded mainly in southern stations while eggs were found only at one station, away from shore (Figure 5). TSI diagram revealed that abundance of ichthyoplankton was associated with all water masses presented during this season (Figure 6a).

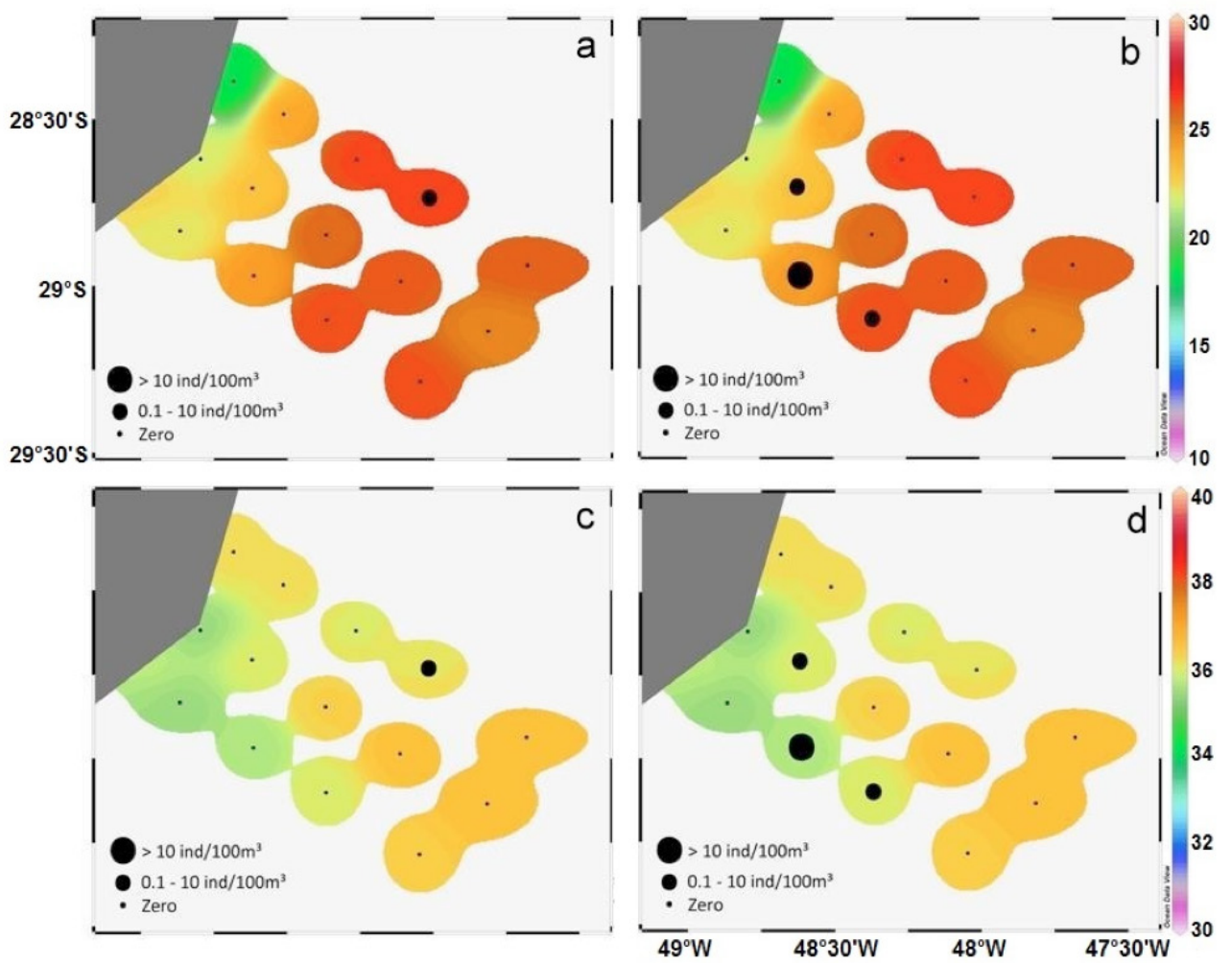

Figure 5 - Distributional patterns observed in Santa Marta Cape during summer 2007. Abundance of E. anchoita eggs (a,c) and larvae $(b, d)$. Temperature $(a, b)$ and salinity $(c, d)$ are represented by colors according to the vertical palette.
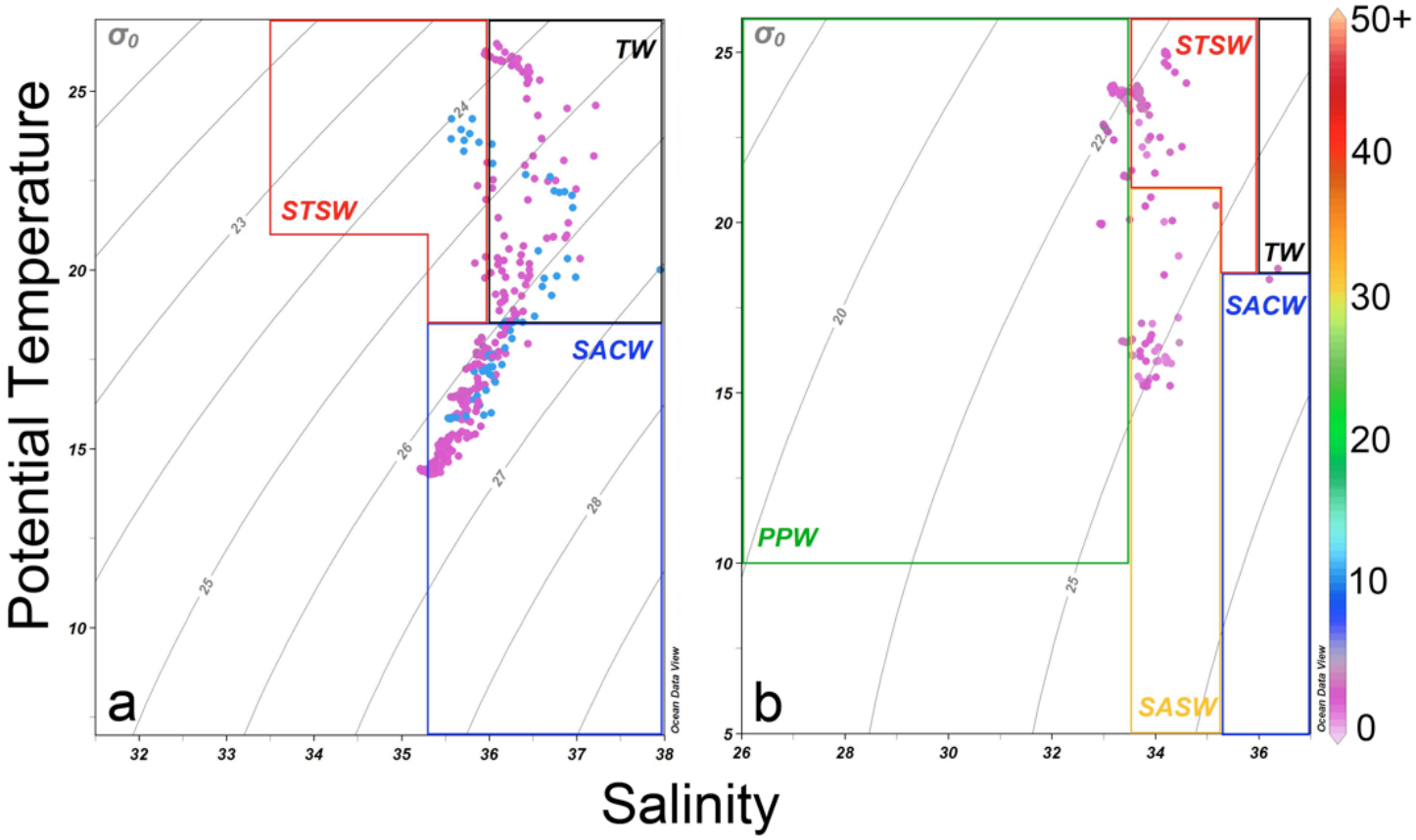

Figure 6 - TSI diagrams with eggs and larvae abundance across different water masses during summer 2007. a) Santa Marta Cape. b) Albardão. Color bar represents ichthyoplankton abundance (ind.100m-3). 
Off Albardão, maximum surface temperature was $25.02^{\circ} \mathrm{C}$ and minimum $22.88^{\circ} \mathrm{C}$ (Figure $7 a, b$ ). Surface salinity varied from 32.63 to 34.18 being almost homogeneous (Figure 7c,d). Ichthyoplankton abundance was high along coastal areas (Figure 7) whereas eggs were presented only at one coastal station (Figure 7a,c). TSI diagram showed that abundance of ichthyoplankton was mainly associated to low salinity waters from STSW, PPW and SASW (Figure 6b).

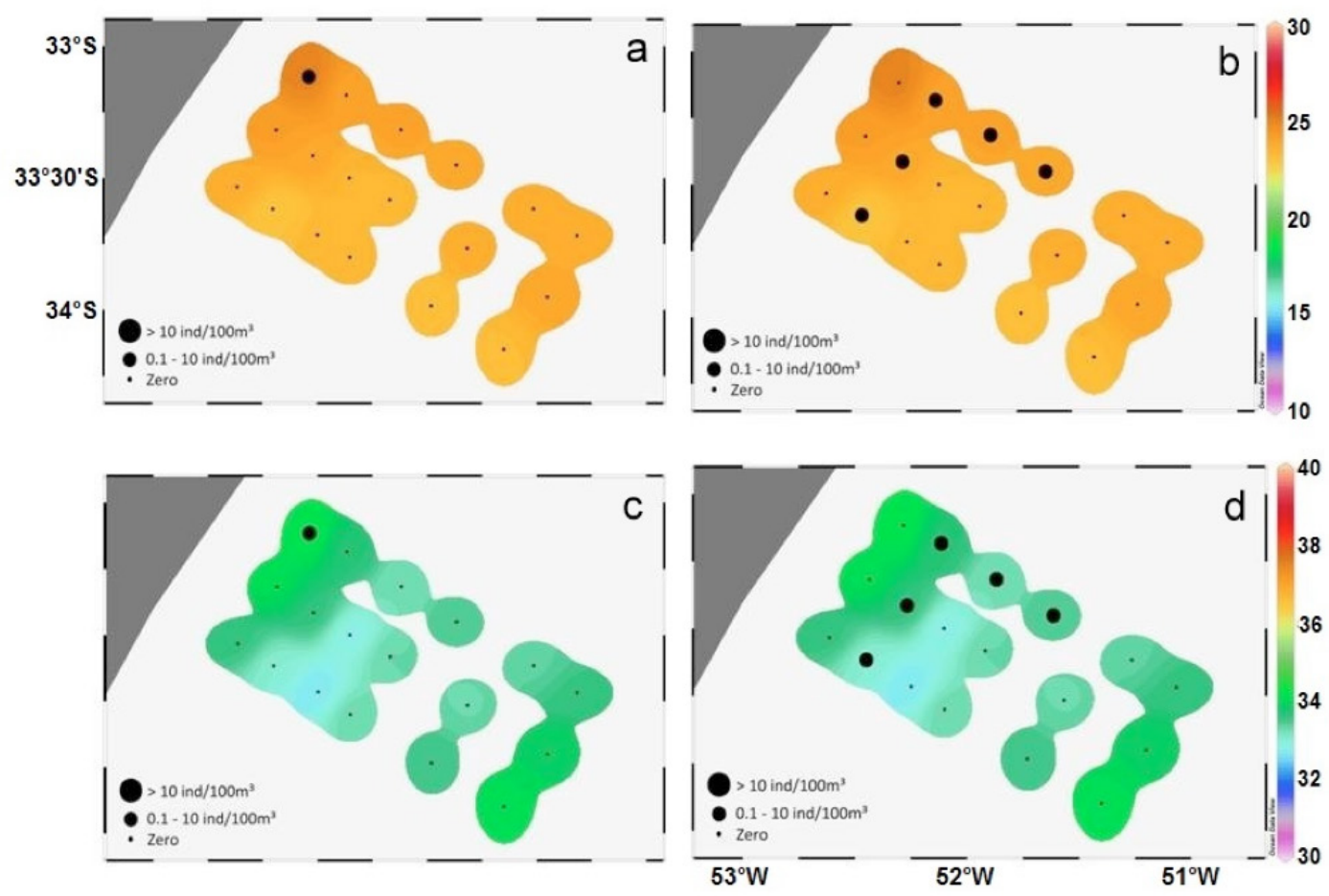

Figure 7 - Distributional patterns observed in Albardão during summer 2007. Abundance of E. anchoita eggs (a,c) and larvae (b,d). Temperature $(a, b)$ and salinity $(c, d)$ are represented by colors according to the vertical palette.

\section{DISCUSSION}

The pronounced seasonal difference in the number of fish eggs and larvae observed is linked to the spawning cycle of the adults of $E$. anchoita in the region. Results showed overwhelming number of eggs and larvae during winter, suggesting seasonal changes in spawning activity of this species. Anchovy spawns intensively off southern Brazil during winter and early spring (Lima \& Castello, 1995). At both seasons, the largest concentration of anchovy eggs and larvae were recorded in coastal areas with low salinity. This proximity to the coast and absence in offshore stations characterize these larvae as shore fish larvae (Sabatés et al., 2007). The same pattern was previously observed in Cape Santa Marta Grande where Matsuura \& Kitahara (1995) recorded high abundance of eggs and larvae at coastal stations.

During winter, eggs and larvae were usually present in cold waters $\left(\mathrm{SMC} 17^{\circ} \mathrm{C}-18^{\circ} \mathrm{C}\right.$ and Albardão $12^{\circ} \mathrm{C}-13^{\circ} \mathrm{C}$ ) however studies performed in higher latitude regions than in this study, (Ciechomski, 1968) pointed out that $E$. anchoita larvae cannot be found in temperatures lower than $11^{\circ} \mathrm{C}$. During summer, the surface temperature was homogeneous and only a small amount of ichthyoplankton was collected. This small amount precludes any inferences about physical-biological relationship. However, Matsuura et al. (1985) suggest that anchovy also choose colder water to spawn during summer.

In summer 2007 a weak upwelling was identified in Santa Marta Cape due to wind changes from NE to S/SE (Campos, 2010). Despite weak, the occurrence of upwelling during summer in that region favors abundance of suitable food (zooplankton), as a consequence of high primary production (Resgalla Jr. et al., 2001). Although food availability, a decrease in anchovy larvae abundance during this season was registered suggesting that other factors act in synergy to determine larvae distribution and abundance.

The decrease in abundance of eggs and larvae of $E$. anchoita during summer can be understood in two ways: first, as a protection strategy to larval mortality caused by offshore transport to unfavorable areas (Santos et al., 2004). Santos et al. (2001) suggested that the intensity and frequency of upwelling events during spawning season should impact negatively the recruitment of small pelagic species due to offshore advection. On the contrary, the highest abundance of ichthyoplankton during winter is the result of 
E. anchoita spawning combined with Ekman transport directed onshore (Lima \& Castello, 1995) where anchovy larvae can find suitable conditions. Second, despite food enrichment during summer, higher feeding success of anchovy larvae was observed for winter (Vasconcellos et al., 1998). This suggests the combined effects of freshwater run-off associated to high concentration of organic and suspended matter and biological production (Muelbert el al., 2008) on the feeding success of larvae, which may not depend only on food concentration (Vasconcellos et al., 1998).

High concentration of eggs and larvae of the Engraulis genus is associated to low salinity waters from river runoff, but depending on species or region the season with peak of abundance is not the same (Palomera, 1992; Olivar \& Sabatés, 1997, Muelbert et al., 2008). According to TSI diagram and maps elaborated for Albardão and Santa Marta Cape, E. anchoita was positively related with water from Río de la Plata mainly during winter when the input of freshwater is large due to combination of increased continental precipitation and wind stress (Piola et al., 2008). On the other hand, some studies presented a negative correlation between catches of Engraulis japonica larvae and river discharges (Lee \& Lee, 2004) as a result of their optimal osmotic pressure (Lee et al., 1990), ocean currents (Funakoshi, 1988) and suitable food (Mitani \& Hasegawa, 1988) in Pacific Ocean.

The large abundance of anchovy eggs and larvae in PPW for both areas can be related not only to their physical characteristics, but also to high concentrations of organic and suspended matter associated to this water mass (Muelbert el al., 2008). This characteristic leads to increase in primary and consequently secondary productivity, resulting in more available resource for $E$. anchoita larvae.

The results provided in this study support that cross-shore distribution of early stages of $E$. anchoita is influenced by water discharge from Río de la Plata and upwelling at Santa Marta Cape, leading to heterogeneous distribution pattern. Likewise anchovies around the world, that tend to utilize different oceanography events associated to spawning and to nursery areas (Castro et al., 2000), larvae of $E$. anchoita are very well adapted to the environmental changes caused by local oceanographic events through year.

\section{REFERENCE}

Acha, E.M.; Miazan, H.W.; Guerrero, R.A.; Favero, M. \& Bava, J. 2004. Marine fronts at the continental shelves of austral South America physical and ecological processes. J Marine Syst. 44:83-105. Campos, P.C. 2010. Efeitos da descarga e dos ventos na região do Cabo de Santa Marta Grande, SC. Tese de Mestrado. Instituto de Oceanografia FURG. 87p.

Castelão, R.M.; Campos, E.J.D. \& Miller, J.L. 2004. A Modelling Study of Coastal Upwelling Driven by Wind and Meanders of the Brazil Current. J Coastal Res 20(3): 662-671.

Castello, J.P. 1997a. Pelagic teleosts. In: Seeliger, U.; Odebrecht, C. \& Castello, J.P. (eds), Subtropical Convergence Environments: The Coast and Sea in the Southwestern Atlantic. Springer. 123-128 pp. Castello, J.P. 1997b. A anchoita (Engraulis anchoita, Engraulidae, Pisces) no Sul do Brasil. Tese de Doutorado. Instituto de Oceanografia - FURG. $84 \mathrm{pp}$.

Ciechomski, J.D. 1968. Distribución y abundancia de huevos y larvas de anchoíta en la región bonaerense y norte patagónica. FAO, Proyecto de Desarrollo Pesquero, Serie Informes Técnicos, 004: 1-11.

Franco, B.C. \& Muelbert, J.H. 2003. Distribuição e composição do ictioplâncton na quebra de plataforma do Sul do Brasil. Atlântica 25(1): 75-86.

Franco, B.C.; Muelbert, J.H. \& Mata, M.M. 2005. O ictioplâncton da quebra da plataforma da região Sul do Brasil e sua relação com as condições ambientais. Programa REVIZEE, MMA. Volume 1. Instituto Oceanográfico - USP, São Paulo, 40p.

Franco, B.C.; Muelbert, J.H. \& Mata, M.M. 2006. Mesoscale physical processes and the distribution and composition of ichthyoplankton on the southern Brazilian shelf break. Fish Oceanogr 15(1): 37-43.

Frere, E., Gandini, P. \& Lichtschein, V. 1996. Variación latitudinal en la dieta del pinguino de magallanes (Spheniscus magellanicus) em La costa patagônica, Argentina. Ornitol Neotrop 7: $35-41$.

Ivanovic, M.L. \& Brunetti, N.E. 1994. Food and feeding of Ilex argentines. Antartic Sci 6: 185-193.

Lee, M.A.; Lee, K.T. \& Ou, H.C. 1990. The larval anchovy fishing ground formation in relation to osmotic pressure changes of the coastal waters along southern Taiwan. J Fish Soc Taiwan 17(4): 233-245.

Lee, M.A.; Lee, K.T. \& Shia, G.Y. 1994. Seasonal changes in commercial catches of anchovy larvae in the southwest coastal waters of Taiwan. J Fish Soc Taiwan 21(1): 49-56.

Lima, I.D. \& Castello, J.P. 1995. Distribution and abundance of South-west Atlantic anchovy spawners (Engraulis anchoita) in relation to oceanographic processes in the southern Brazilian shelf. Fish Oceanogr 4(1): 1-17.

Matsuura, Y; Amaral, J.C.; Tamassia, S.T.J. \& Sato, G. 1985. Ocorrência de peixes pelágicos e estrutura 
oceanográfica da região entre Cabo de São Tomé (RJ) e Cananéia (SP), em janeiro-fevereiro/1979. Téc. Doc. Sér. PDP/SUDEPE 33: 3-73.

Matsuura, Y; Spach, H.L. \& Katsuragawa, M. 1992. Comparison of spawning patterns of the Brazilian sardine (Sardinella brasiliensis) and anchoita (Engraulis anchoita) in Ubatuba region, southern Brazil during 1985 through 1988. Bol Inst Oceanogr 40(1/2): 101-115.

Matsuura, Y. \& Kitahara, E.M. 1995. Horizontal and vertical distribution of anchovy Engraulis anchoita eggs and larvae off Cape Santa Marta Grande in southern Brazil. Arch Fish Mar Res 42(3): 239-250.

Matsuura, Y. 1996. A probable cause of recruitment failure of the Brazilian sardine Sardinella aurita population during the $1974 / 75$ spawing season. S Afr Mar Sci 17: 29-35.

Mitani, I.. 1988. Food habits of Japanese anchovy in the shirasu fishing ground within Sagami Bay. Nippon Suisan Gakkaishi. 54( 1): 1859-1865.

Muelbert, J.H.; Acha, M.; Miazan, H.; Guerrero, R.; Reta, R.; Braga, E.S.; Garcia, V.M.T; Barasategui, A.; Gomez-Erache, M. \& Ramírez, F. 2008. Biological, physical and chemical properties at the Subtropical Shelf Front Zone in the SW Atlantic Continental Shelf. Cont Shelf Res 28: 1662-1673.

Möller Jr., O.O.; Piola, A.R.; Freitas, A.C. \& Campos, E.J.D., 2008. The effects of river discharge and seasonal winds on the shelf off southeastern South America. Cont Shelf Res 28: 1607-1624.

Munk, P.; Larsson, P.O.; Danielsen, D. \& Moksness, E. 1999. Variability in frontal zone formation and distribution of gadoid fish larvae at the shelf break in the northeastern North Sea. Mar Ecol-Prog Ser 177: 221-233.

Naya, D.E. 2002. Diet of South American fork seals (Arctocephalos australis) in Isla de Lobos, Uruguay. Mar Mam Sci 18: 734-754.

Norcross, B.L. \& Shaw, R.F. 1984. Oceanic and estuarine transport of fish eggs and larvae: A review. T Am Fish Soc 113: 153-165.

Olivar, M.P. \& Sabatés, A. 1997. Vertical distribution of fish larvae in the north-west Mediterranean Sea in spring. Mar Biol 129: 289-300.
Palomera, I. 1992. Spawing of anchovy Engraulis encrasicolus, in the North-Western Mediterranean relative to hydrographic features in the region. Mar Ecol-Prog Ser 79: 215-223.

Piola, A.R.; Campos, E.J.D.; Möller Jr., O.O.; Charo, M. \& Martinez, C. 2000. Subtropical Shelf Front off eastern South America. J Geophys Res 105(C3): 6565-6578.

Piola, A.R.; Möller Jr., O.O.; Guerrero, R. \& Campos, E.J.D. 2008. Variability of the subtropical shelf front off eastern South America: Winter 2003 and summer 2004. Cont Shelf Res 28: 1639-1648.

Resgalla Jr., C.; De la Rocha, C. \& Montú, M. 2001. The influence of Ekman transport on zooplankton biomass variability off southern Brazil. J Plankton Res 23(6): 641-650.

Sabatés, A. \& Olivar, M.P. 1996. Variation of larval fish distributions associated with variability in the location of a shelf-slope front. Mar Ecol-Progr Ser 135: $11-20$.

Sabatés, A.; Olivar, M.P.; Salat, J.; Palomera, I \& Alemany. 2007. Physical and biological process controlling the distribution of fish larvae in the NW Mediterranean. Progr Oceanog 74: 355-376.

Santos, A.M.P.; Borges, M.F. \& Groom, S. 2001. Sardine and horse mackerel recruitment and upwelling off Portugal. ICES J Mar Sci 58: 589-596.

Santos, A.M.P; Peliz, A.; Dubert, J.; Oliveira, P.B.; Angélico, M.M. \& Ré, P. 2004. Impacto of a winter upwelling event on the distribution and transport of sardine (Sardina pilchardus) eggs and larvae off western Iberia: a retention mechanism. Cont Shelf Res 24: 149-165.

Santos, A.M.P.; Ré, P.; Santos, A. \& Peliz, A. 2006. Vertical distribution of the European sardine (Sardina pilchardus) larvae its implications for their survival. J Plankton Res 28(5): 523-532.

Zar, J.H. 1999. Biostatistical analysis. Prentice Hall Inc., llinois, 710p. 